\title{
АКТУАЛЬНІ ПИТАННЯ РАННЬОÏ ДІАГНОСТИКИ ДІАБЕТИЧНОГО ҐАСТРОПАРЕЗУ У ПРАКТИЦІ СІМЕЙНОГО ЛІКАРЯ
}

\author{
ДВНЗ «Івано-Франківський національний медичний університет»
}

\section{๑І. О. Костіцька}

РЕЗЮМЕ. Метою дослідження стало вивчення питання ранньої діагностики проявів ґастропарезу у хворих на цукровий діабет (ЦД) за допомогою специфічних анкет-опитувальників.

Матеріал і методи. Обстежено 240 хворих на ЦД, яким в якості раннього скринінгу дизмоторики шлунка проведено анкетування з використанням двох опитувальників: оцінки симптомів, характерних для захворювань верхнього відділу шлунково-кишкового тракту «Patient Assessment of Upper Gastrointestinal Disorders-Symptoms» (PAGI-SYM) і визначення індексу проявів ґастропарезу «Gastroparesis Cardinal Symptom Index» (GCSI). Виконано оцінку надійності результатів анкетування з визначенням коефіцієнта внутрішньої відповідності і критеріальної валідності за взаємозв'язками шкал опитувальників із 13С-октаноєвим дихальним тестом (13С-ОДТ), що визначали за допомогою коефіцієнта кореляції. Статистичну обробку результатів проводили за допомогою програми SPSS15.

Результати. У 36,6 \% хворих на ЦД 1 типу та у 43,3 \% хворих на ЦД 2 типу виявлено симптоми діабетичного ґастропарезу (ДҐ). Встановлена взаємозалежність клінічних проявів ускладнення із результатами 13С-ОДТ. Запропоновано діагностичний алгоритм: ретельне вивчення скарг обстеженого і даних анамнезу життя i захворювання, фізикальний огляд з подальшим використанням опитувальників GCSI та оцінкою результатів. Якщо сума балів становила від 1 до 11 - діагностували легкий ступінь Дґ, 12-22 бали - середньої тяжкості, 23-33 бали тяжкий, більше 34 балів-дуже тяжкий. Для оцінки М-ЕФ шлунка виконано 13С-ОДт: нормальний показник - при часі напіввиведення (Т 1 1 2) 40-75 хвилин вмісту шлунка у дванадцятипалу кишку, прискорення моторики, якщо Т $1 \frac{1}{2}$ менше 40 хвилин, сповільнення моторики легкого ступеня - 75-95 хвилин, уповільнення середнього ступеня - від 96 до 115 хвилин, уповільнення тяжкого ступеня - більше 115 хвилин. Даний діагностичний алгоритм дозволяє сімейним лікарям своєчасно діагностувати початкові ознаки Дґ.

Висновок. Рутинне використання специфічних опитувальників сприяє запобіганню невиправданій гіпердіагностиці, дозволяє визначити ступінь тяжкості ґастропарезу у хворих на ЦД та забезпечити ефективність терапії.

КЛючовІ СлОВА: анкетування; цукровий діабет; діабетичний ґастропарез; сімейний лікар.

Вступ. Протягом останніх років цукровий діабет (ЦД), поряд із серцево-судининими та онкологічними захворюваннями, досягає масштабів неінфекційної епідемії. Дані діабетичного атласу (2015 р.) свідчать, що у світі налічується 415 млн осіб, хворих на ЦД. Враховуючи важливість і соціальне значення хронічних ускладнень зі сторони більшості органів і систем внаслідок основного захворювання науковці проводять активний пошук сучасних легкодоступних та чутливих методів ранньої їх діагностики [14]. Лікарям добре відомі клінічні прояви макро- (інфаркт міокарда, інсульт, гангрени нижніх кінцівок) і мікросудинних (ретино-, нефро-, ангіопатії) ускладнень ЦД, але впродовж останнього десятиліття науковці все більше акцентують увагу медичного суспільства на ураженні у даної групи пацієнтів $[3,6,12]$ шлунково-кишкового тракту. Безсимптомні, приховані форми гастроінтестинальної діабетичної автономної нейропатії (ДАН) діагностують у 50$60 \%$ хворих на ЦД $[5,7]$. Не підозрюючи у більшій кількості випадків, сімейні лікарі, терапевти і вузькопрофільні спеціалісти виявляють різноманітні «маски» діабетичного ґастропарезу (Дґ). А лікарі функціональної діагностики, ендоскопісти у заключеннях часто описують наявність у шлунку рештків їжі або переповнення ними навіть після 12 годинного голоду у хворих на ЦД. Іноді анестезіологи під час введення наркозу даній ґрупі пацієнтів виявляють випадки аспірації вмісту шлунка і блювотних мас. Проте з більш тяжкими проявами дизмоторики шлунка зустрічаються гастроентерологи та ендокринологи: постійне відчуття переповнення шлунка, тривалого насичення, різке зниження апетиту, нудота, нестримне блювання, прогресує декомпенсація вуглеводного обміну, що, у свою чергу, викликає різку втрату маси тіла і сприяє лабільному перебігу ЦД із високим ризиком гіпоглікемій. При тяжких стадіях дґ збільшується число госпіталізацій і вартість лікування хворих на ЦД, у результаті зниження апетиту, десинхронізації часу настання дії інсуліну і надходження їжі в тонку кишку, а також порушення кінетики таблетованих пероральних цукрознижувальних препаратів.

Незважаючи на впровадження засобів науково-технічного прогресу у медицину, Дґ нерідко залишається пізно діагностованим ускладненням, яке вкрай складно піддається терапії, значно погіршує якість життя (ЯЖ) пацієнтів і визначає його не- 
Огляди літератури, оригінальні дослідження, погляд на проблему

сприятливий прогноз, а також потенціює ріст інвалідності і смертності працездатного населення $[8,10,12]$.

Тому важливим етапом у розвитку сучасної системи охорони здоров'я із розширенням технічних та інформаційних можливостей $є$ розробка/удосконалення й впровадження діагностичних алгоритмів для вчасного виявлення хронічних ускладнень ЦД.

У щоденній медичній практиці у високоцивілізованих країнах світу лікарі різних спеціальностей широко використовують анкетування пацієнтів, які перед консультацією спеціаліста самостійно заповнюють з використанням електронних чи паперових носіїв опитувальники, відповіді на блоки запитань подають для підрахунку балів медичній сестрі, а у день призначеного візиту після інтерпретації результатів терапевт може скоординувати подальший маршрут хворого [2, 11, 15]. Наявність різних видів опитувальників свідчить про цікавість медичного суспільства до суб'єктивної картини захворювання.

Впровадження у щоденну лікарську практику анкет-опитувальників базується на ретельному аналізі даних сучасної медичної літератури і міжнародних досліджень $[6,7,13]$. Визначення ступеня тяжкості і провідних симптомокомплексів у групах хворих на гастроезофагеальну рефлюксну хворобу, диспептичний синдромом і ґастропарез виконано за результатами інтерв'ю з респондентами і лікарями на основі відповідей на 20 питань опитувальника «Оцінка симптомів, характерних для захворювань верхнього відділу шлунковокишкового тракту» (Patient Assessment of Upper Gastrointestinal Disorders-Symptoms - PAGI-SYM) i аналізу даних фізикального огляду пацієнтів $[10,11]$. Питання опитувальника об'єднані у 6 підшкал: печія/регургітація (7 питань), нудота/блювання (3 питання), відчуття поспрандіального переповнення їжі/раннього насичення (4 питання), метеоризм/здуття (2 питання), біль у верхній частині живота (2 питання), біль у нижній частині живота (2 питання). Згідно з методичними вказівками щодо підрахунку результатів анкетування виконують інтерпретацію суб'єктивних ознак за 5 бальною шкалою, де 0 - відсутній, 1 - дуже легкий, 2 - легкий, 3 - середньої тяжкості, 4 - тяжкий, 5 - дуже тяжкий. У ряді наукових праць доведено, що для надійності даних слід використовувати оцінку суми балів за опитувальником, а не його середнє значення за шкалами $[6,11]$. Сума балів PAGI-SYM від 1 до 20 балів відповідає дуже легкому ступеню тяжкості ґастропарезу, 21-40 балів легкому ступеню, 41-60 балів - середньої тяжкості, 61-80 балів - тяжкому перебігу, 81-100 балів дуже тяжкому.
У 2004 р. американські гастроентерологи запропонували спеціальний опитувальник Gastroparesis Cardinal Symptom Index (GCSI), який базується на трьох групах запитань, що об'єднані у шкали: відчуття переповнення після прийому їжі/ раннього насичення (4 ознаки), нудота/блювання (3 ознаки), здуття живота (2 ознаки). Оцінку тяжкості симптомів виконували за 5-бальною шкалою, де 0 - відсутній, 1 - дуже легкий, 2 - легкий, 3 - середньої тяжкості, 4 - тяжкий, 5 - дуже тяжкий перебіг хвороби. Сума усіх балів від 1 до 11 свідчить про легкий ступінь тяжкості, тоді як від 12 до 22 балів - середньої тяжкості, від 23 до 33 балів - тяжкий, при значенні більше 34 балів дуже тяжкий. У своїх відповідях хворі повинні оцінити за шкалою ступеня тяжкості прояви симптомів впродовж останніх двох тижнів. За допомогою даного виду анкетування лікар/пацієнт можуть швидко проаналізувати динаміку симптомів з плином часу і визначити ефективність медикаментозної терапії. У 2009 році проведено модифікацію опитувальника (GCSI - Daily Diary, GCSI-DD) для щоденної оцінки симптомів ґастропарезу $[9,15]$.

Єдиної думки лікарів-науковців щодо можливості використання тільки одного опитувальника (GCSI) для експрес-анкетування немає $[12,15]$. Деякі автори у своїх роботах стверджують, що опитувальник GCSI не є надійним у визначенні специфічних симптомів парезу шлунка, оскільки на основі шкал будь-якого анкетування не можна у повному обсязі визначити усі предиктори розвитку патологічного стану $[7,8]$. Інші вчені у групових дослідженнях проводили визначення надійності результатів анкетування - здатність опитувальника встановлювати постійні і точні визначення за допомогою коефіцієнта а-Кронбаха. Якщо його показник $\geq 0,7$, результат слід вважати задовільним. У більшості робіт встановлено високу інформативність і надійність даного виду обстеження хворих $[2,9,11]$. На основі огляду рекомендацій експертного комітету гастроентерологів і результатів епідеміологічних досліджень можна зробити висновок, що GCSI - надійний інструмент для ранньої стратифікації симптомів ґастропарезу та оцінки відповіді на лікування.

Мета дослідження - удосконалити методи діагностики початкових проявів Дґ за даними анкет-опитувальників (PAGI-SYM, GCSI) і результатами 13С-ОДТ.

Матеріал і методи дослідження. Після підписання інформованої згоди ми обстежили 240 хворих на ЦД. У діагностиці ЦД 1 і 2 типів та при оцінці ступеня компенсації вуглеводного обміну керувались національними стандартами (Накази МО3 України № 574 від 05.08.2009р., № 1118 від 21.12.2012 р., № 1021 від 29.12.2014 р.). Клінічне 
Огляди літератури, оригінальні дослідження, погляд на проблему обстеження пацієнтів складалося із детального аналізу анамнестичних даних, анкетування PAGISYM і GCSI, результатів фізикального огляду, стандартного набору лабораторних показників, клінічного і біохімічного аналізу крові, оцінки стану компенсації вуглеводного обміну.

Для оцінки М-ЕФ шлунка всім обстеженим запропоновано 13С-октаноєвий дихальний тест (13С-ОДТ) $[4,14]$. Оцінку результатів проведено за часом напіввиведення (Т 1/2) вмісту шлунка у два-

надцятипалу кишку: нормальний показник Т $1 / 2$ складає 40-75 хвилин, прискорення моторики діагностували, якщо Т $1 \frac{2}{2}$ менше 40 хвилин, легкий ступінь сповільнення моторики - 75-95 хвилин, від 96 до 115 хвилин - уповільнення середнього ступеня, більше 115 хвилин - уповільнення тяжкого ступеня.

Основні клініко-лабораторні та інструментальні показники, за якими проводилася оцінка обстежених на момент первинного огляду, описані у таблиці 1.

Таблиця 1. Характеристика включених у дослідження пацієнтів

\begin{tabular}{|c|c|c|}
\hline \multirow{2}{*}{ Показники } & \multicolumn{2}{|c|}{ Результати } \\
\hline & ЦД 1 типу (n=120) & ЦД 2 типу ( $n=120)$ \\
\hline Стать (чол./жін.) & $58 / 62$ & $55 / 65$ \\
\hline Вік, роки & $41,2 \pm 5,8$ & $59,4 \pm 3,9$ \\
\hline Тривалість ЦД, роки & $8,3 \pm 1,3$ & $9,4 \pm 1,5$ \\
\hline Куріння, п ( \%) & $54(45,0)$ & $68(56,7)$ \\
\hline Обтяжений спадковий анамнез на ЦД, n (\%) & $55(45,8)$ & $79(65,8)$ \\
\hline Індекс маси тіла, кг/м² & $26,6 \pm 1,4$ & $31,3 \pm 2,2$ \\
\hline \multicolumn{3}{|l|}{ Показники вуглеводного обміну } \\
\hline Глікозильований гемоглобін, \% & $9,2 \pm 1,2$ & $9,7 \pm 1,6$ \\
\hline Прандіальна глікемія, ммоль/л & $8,2 \pm 0,9$ & $9,4 \pm 1,3$ \\
\hline Постпрандіальна глікемія, ммоль/л & $9,8 \pm 1,5$ & $10,3 \pm 0,9$ \\
\hline Епізоди гіпоглікемій, n ( \%) & $41(34,2)$ & $20(16,7)$ \\
\hline Частота кетоацидозу, n ( \%) & $11(9,2)$ & $2(1,7)$ \\
\hline \multicolumn{3}{|c|}{ Хронічні ускладнення ЦД } \\
\hline Периферійна полінейропатія, n ( \%) & $110(91,7)$ & $118(98,3)$ \\
\hline Синдром діабетичної стопи, n ( \%) & $18(15,0)$ & $34(28,3)$ \\
\hline Ангіопатія судин нижніх кінцівок, n ( \%) & $52(43,3)$ & $110(91,7$ \\
\hline Ретинопатія, n (\%) & $58(48,3)$ & $77(64,2)$ \\
\hline Нефропатія, n ( \%) & $10(8,3$ & $28(23,3)$ \\
\hline Гепатоз, n ( \%) & $14(11,7)$ & $59(49,2)$ \\
\hline
\end{tabular}

Критеріями виключення з дослідження були наявність в анамнезі тяжких захворювань шлунково-кишкового тракту, нирок; хронічних захворювань серцево-судинної системи з розвитком недостатності кровообігу вище II функціонального класу за класифікацією NYHA; вагітність, лактація; онкологічні захворювання; системні захворювання сполучної тканини; хронічні захворювання з алергічним компонентом у ґенезі (бронхіальна астма тощо); психічні хвороби; гостре запальне та/або загострення хронічного запального захворювання; інші ендокринні захворювання.

Для всіх пацієнтів дотримано заходів щодо безпеки здоров'я, прав пацієнта, людської гідності та морально-етичних норм відповідно до принципів Гельсінкської декларації прав людини, Кон- венції Ради Європи про права людини і біомедицину та відповідних законів України.

Статистичну обробку результатів проводили за допомогою програми IBM SPSS15: показники описової статистики з інтервальним типом шкали були представлені у вигляді середніх значень і стандартних відхилень. Якісні показники визначені у вигляді абсолютних частот і часток у групі у відсотках. Використовували коефіцієнт кореляції Спірмена, коефіцієнт внутрішньої відповідності (коефіцієнт а-Кронбаха), значення р<0,05 вважали вірогідним.

Результати й обговорення. У більшої частини хворих на ЦД 1 (91,7 \%) і 2 (98,3 \%) типів діагностовано діабетичну полінейропатію, серед яких за результатами анкетування (PAGI-SYM, GCSI) у 
Огляди літератури, оригінальні дослідження, погляд на проблему

36,6-43,3 \% обстежених виявлено симптоми дґ: серед хворих на ЦД 1 типу дуже легкого ступеня у 4 (3,3 \%) хворих, легкого ступеня - у $17(14,2 \%)$ осіб, середнього ступеня - у 15 (12,5\%), тяжкий перебіг даного ускладнення вияявлений у 7 (5,8 \%) обстежених і тільки один $(0,8 \%)$ пацієнт вказав на дуже тяжкі прояви ґастропарезу. Серед хворих на ЦД 2 типу тільки в одного $(0,8 \%)$ хворого були дуже легкі прояви ґастропарезу, у 20 $(16,7 \%)$ обстежених виявлено ознаки дизмоторики шлунка легкого ступеня, у 22 (18,3\%) - середнього ступеня тяжкості, і тільки у $9(7,5 \%)$ пацієнтів діагностовано тяжкий ступінь Дґ. Слід зазна- чити, що розбіжностей між оцінкою результатів опитувальників PAGI-SYM й GCSI не було. Тому для експерес-анкетування та економії часу як пацієнта, так і лікаря, у щоденній медичній практиці слід розглянути можливість використання тільки опитувальника GCSI.

Виконано оцінку надійності анкетування GCSI з визначенням коефіцієнта внутрішньої відповідності (коефіцієнт а-Кронбаха) для кожної шкали у хворих на ЦД 1 і ЦД 2 типів. У таблиці 2 наведено результати. За всіма шкалами коефіцієнт а-Кронбаха перевищує 0,9, що свідчить про надійність опитувальника GCSI у хворих з цією патологією.

Таблиця 2. Значення коефіцієнта а-Кронбаха для шкал опитувальника GCSI

\begin{tabular}{|l|c|c|c|}
\hline \multicolumn{1}{|c|}{ Шкали опитувальника } & Кількість & \multicolumn{2}{|c|}{ Коефіцієнт а-Кронбаха } \\
\cline { 3 - 4 } & питань & ЦД 1 типу & ЦД 2 типу \\
\hline Відчуття переповнення після прийому їжі/раннього насичення & 4 & 0,93 & 0,93 \\
\hline Нудота/блювання & 3 & 0,97 & 0,98 \\
\hline Здуття живота & 2 & 0,94 & 0,97 \\
\hline
\end{tabular}

Для визначення критеріальної валідністі між шкалами опитувальників PAGI-SYM і GCSI та встановлення взаємозв' язку із швидкістю М-ЕФ шлун- ка за результатами 13С-ОДт визначено коефіцієнт кореляції Спірмена (г). Результати аналізу наведено у таблиці 3.

Таблиця 3. Взаємозв'язок шкал опитувальників (PAGI-SYM, GCSI) із показником 13С-ОДТ, хв

\begin{tabular}{|c|c|c|c|c|}
\hline \multirow{3}{*}{ Шкали GCSI, бали } & \multicolumn{4}{|c|}{ Коефіцієнт кореляції Спірмена (г) } \\
\hline & \multicolumn{2}{|c|}{$\begin{array}{c}\text { загальний показник PAGI-SYM, } \\
\text { бали }\end{array}$} & \multicolumn{2}{|c|}{ 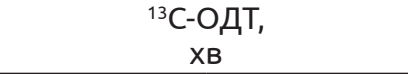 } \\
\hline & ЦД 1 типу & ЦД 2 типу & ЦД 1 типу & ЦД 2 типу \\
\hline Нудота & $0,97^{*}$ & $0,96^{*}$ & $0,92 *$ & $0,93 *$ \\
\hline Поклики до блювання (без блювотних мас) & $0,98 *$ & $0,96 *$ & $0,92 *$ & $0,88^{*}$ \\
\hline Блювання & $0,80 *$ & $0,72 *$ & $0,87 *$ & $0,85^{*}$ \\
\hline Відчуття насичення їжею & $0,98 *$ & $0,95 *$ & $0,82 *$ & $0,56^{*}$ \\
\hline $\begin{array}{l}\text { Не змогли проковтнути нормального роз- } \\
\text { міру їжу }\end{array}$ & $0,97 *$ & $0,96^{*}$ & $0,87^{*}$ & $0,80 *$ \\
\hline Відчуття переповнення після прийому їжі & $0,98 *$ & $0,95 *$ & $0,88^{*}$ & $0,80 *$ \\
\hline Втрата апетиту & $0,98^{*}$ & $0,96 *$ & $0,84^{*}$ & $0,79 *$ \\
\hline Метеоризм (відчуття здуття живота) & $0,98^{*}$ & $0,96^{*}$ & $0,91 *$ & $0,75^{*}$ \\
\hline Живіт помітно збільшений у розмірі & $0,97 *$ & $0,97 *$ & $0,90 *$ & $0,81 *$ \\
\hline Загальний показник GCSI, бали & $0,99 *$ & $0,99 *$ & $0,91 *$ & $0,85^{*}$ \\
\hline Загальний показник PAGI-SYM, бали & 1 & 1 & $0,92 *$ & $0,93 *$ \\
\hline
\end{tabular}

Примітка: * $-p<0,01$.

Отримані результати свідчать про наявність значимої $(p<0,01)$ кореляційної залежності між усіма шкалами опитувальника і ступенем уповільнення М-ЕФ шлунка за результатами 13С-ОДТ. Отже, для початкової діагностики навіть безсимптомних чи прихованих форм ДҐ одну із провідних ролей відіграє анкетування, яке за короткий час прицільно спрямовує лікаря і пацієнта на оцінку ряду важливих проявів захворювання.

у більшості випадків клініцисти недооцінюють роль суб'єктивної оцінки пацієнтами ступеня тяжкості і перебігу симптомів ґастропарезу, проте при випробуванні нових лікарських засобів, навіть при вивченні віддалених наслідків, через 5-10 років, даний вид обстеження вважають високоефективним і достовірним $[1,6,10]$. Тому слід широко впроваджувати у рутинну практику сімейних лікарів і спеціалістів вузького профілю використання опитувальників, за оцінкою результатів яких можна виявити важливі скарги, після чого правильно з малими фінансовими затратами вибрати лабораторно-інструментальні мето- 
Огляди літератури, оригінальні дослідження, погляд на проблему

ди обстеження для підтвердження чи виключення діагнозу.

Покроковий діагностичний алгоритм раннього скринінгу уповільнення М-ЕФ шлунка у хворих на ЦД на першому етапі складається із детального аналізу анамнестичних даних, анкетування GCSI, результатів фізикального огляду, стандартного набору лабораторних-інструментальних показників. На другому етапі, якщо за результатами анкетування сума балів опитувальника GCSI вище 12 балів, з метою дообстеження за допомогою 13С-ОДТ визначають ступінь тяжкості уповільнення М-ЕФ шлунка.

Висновки. За результатами анкетування (PAGI-SYM, GCSI) у 36,6 \% осі6, хворих на ЦД 1 типу, та у 43,3 \% хворих на ЦД 2 типу виявлено симптоми ДГ.

Встановлена взаємозалежність клінічних проявів ускладнення (GCSI)) із результатами 13С-ОДТ.

Рутинне використання сімейними лікарями чи вузькопрофільними спеціалістами специфічних опитувальників сприяє запобіганню невиправданій гіпердіагностиці, дозволяє визначити ступінь тяжкості ґастропарезу у хворих на ЦД та призначити ефективну терапію.

Перспективи подальших досліджень. Доцільно вивчити результати анкетування у ґрупі хворих з ознаками Дґ на фоні базової, патогенетичної і симптоматичної терапій.

\section{ЛІТЕРАТУРА}

1. Звягінцева Т. Д. Функціональні захворювання органів травлення та їх поєднання у світлі сучасних уявлень: від патогенезу до лікування // Т. Д. Звягінцева, А. І. Чернобай // Сучасна гастроентерологія. - 2015. № 3 (83). - С. 61-72.

2. Исмаилов С. И. Роль опросников в оценке качества жизни пациентов с сахарным диабетом (обзор литературы) // С. И. Исмаилов, С. У. Муминова // Международный эндокринологический журнал. - 2016. - № 2 (74). С. $152-157$.

3. Диабетический гастропарез // В. М. Махов, Г. А. Мельниченко, И. Ю. Буденная [и др.] // РМЖ. - 2014. № 15, С. 1133-1136.

4. Передерий В. Г. Нервно-мышечная функция желудка в норме и при патологии: современные методы диагностики и коррекции : метод. посо6. / В. Г. Передерий, С. М. Ткач. - К. : РПХ «ФЕРЗЬ». - 2012. - 48 с.

5. Трухан Д. И. Гастроэнтерологические нарушения у пациентов с сахарным диабетом / Д. И. Трухан, Л. В. Тарасова, Л. Ю. Трухан // Справочник врача общей практики. - 2013. - № 8. - С. 51-59.

6. Camilleri M. Epidemiology, mechanisms, and management of diabetic gastroparesis / M. Camilleri, A. E. Bharucha, G. Farrugia // Clinical Gastroenterology and Hepatology. - 2011. - Vol. 9 (1). - P. 5-12.

7. Gastroparesis among type 1 and tpe 2 dabetic ptients in the United Arab Emirates / G. Darwiche, S. K. Mohammed, N. Aldawi [et al.] // Journal of Diabetes Mellitus. - 2014. http://dx.doi.org/10.4236/jdm.2014.42016.

8. Halland M. Relationship between control of glycemia and gastric emptying disturbances in diabetes melli- tus / M. Halland, A. E. Bharucha // Gastroenterol. Hepatol. - 2016. - Vol. 14 (7). - P. 929-936.

9. Diabetic gastroparesis: functional/morphologic background, diagnosis, and treatment options/V. J. Horváth, F. Izbéki, C. Lengyel [et al.] //Curr. Diab. Rep.-2014. -Vol. 14.P. 527. http://dx.doi.org/10.1007/s11892-014-0527-8.

10. Kashyap P. Diabetic gastroparesis: what we have learned and had to unlearn in the past 5 years / P. Kashyap, G. Farrugia // Gut. - 2010. - Vol. 59. - P. 1716-1726.

11. Relationship between symptom pattern, assessed by the PAGI-SYM questionnaire, and gastric sensorimotor dysfunction in functional dyspepsia / S. Kindt, D. Dubois, L. V. Oudenhove [et al.] // Neurogastroenterol. Motil. - 2009. -Vol.21.-P.1183-e105.doi:10.1111/j.1365-2982.2009.01374.

12. Gastrointestinal complications of diabetes mellitus / B. Krishnan, S. Babu, J. Walker [et al.] // World Journal of Diabetes. - 2013. - Vol. 4. - P. 51-63. http://dx.doi. org/10.4239/wjd.v4.i3.51.

13. Diabetic gastroparesis - from diagnosis to gastric electrical stimulation treatment / S. K. Majanović, M. Zelić, A. Belančić [et al.] // Medicina fluminensis. - 2017. - Vol. 1 (53). - P. 50-55. doi: 10.21860/medflum2017_173380.

14. Diabetic neuropathy: a position statement by the American Diabetes Association / R. Pop-Busui, A. J. M. Boulton, E. L. Feldman [et al.] // Diabetes Care. - 2017. - Vol. 40. P. 136-154. doi: 10.2337/dc16-2042.

15. Development and content validity of a gastroparesis cardinal symptom index daily diary / D. A. Revicki, M. Camilleri, B. Kuo [et al.] // Alimentary Pharmacology \& Therapeutics. - 2009. - Vol. 30. - P. 670-680. doi:10.1111/ j.1365-2036.2009.04078.

\section{REFERENCES}

1. Zviahintseva, T.D. \& Chernobai, A.I. (2015). Funktsionalni zakhvoriuvannia orhaniv travlennia ta yikh poiednania u svitli suchasnykh uiavlen: vid patohenezu do likuvannia [Functional disorders of organs of the digestive system and their combinations in the light of modern conceptions]. Suchasna hastroenterolohiia - Modern Gastroenterology, 3, (83), 61-72 [in Ukrainian].

2. Ismailov, S.I. \& Muminova, S.U. (2016). Rol oprosnikov v otsenke kachestva zhizni patsiyentov s sakharnym diabetom (obzor literatury) [The role of questionnaires in the evaluation of quality of life of patients with diabetes mellitus (literature review)]. Mezhdunarodnyy endokrinologicheskiy zhurnal - International Journal of Endocrinology, 2, (74), 152-157 [in Russian]. 
Огляди літератури, оригінальні дослідження, погляд на проблему

3. Makhov, V. M., Melnichenko, G.A., Budennaya, Y.Yu., Volodina, V.T., Glinkina, I.V. \& Zilov, A.V. (2014). Diabeticheskyy gastroparez [Diabetic gastroparesis]. RMZh $-R M J, 15$, 1133-1136 [in Russian].

4. Perederiy, V.G. \& Tkach, S.M. (2012). Nervnomyshechnaya funktsyya zheludka $v$ norme $i$ pri patologii: sovremennye metody diagnostiky i korrektsyi: metod. posob. [Neuromuscular function of the stomach in norm and in pathology: modern methods of diagnosis and correction: method. guide]. RPKh "FERZ" [in Russian].

5. Trukhan, D.I., Tarasova, L.V. \& Trukhan, L.Yu. (2013). Gastroenterologicheskie narusheniya u patsyentov s sakharnym diabetom [Gastroenterological disorders in patients with diabetes mellitus]. Spravochnik vracha obshchey praktiky - General Practitioner's Guide, 8, 51-59. [in Russian].

6. Camilleri, M., Bharucha, A. E., \& Farrugia, G. (2011). Epidemiology, mechanisms, and management of diabetic gastroparesis. Clinical Gastroenterology and Hepatology, 9, (1), 5-12.

7. Darwiche, G., Mohammed, S. K., Aldawi, N., Skaria, S. \& Tesfa, Y. (2014). Gastroparesis among Type 1 and Type 2 Diabetic Patients in the United Arab Emirates. Journal of Diabetes Mellitus, 4, 96-106. http://dx.doi.org/10.4236/ jdm.2014.42016.

8 Halland, M., \& Bharucha, A.E. (2016). Relationship between control of glycemia and gastric emptying disturbances in diabetes mellitus. Clin. Gastroenterol. Hepatol., $14,(7), 929-936$.

9. Horváth, V. J., Izbéki, F., Lengyel, C., Kempler, P. \& Várkonyi, T. (2014). Diabetic gastroparesis: functional/

morphologic background, diagnosis, and treatment options. Curr. Diab. Rep, 14, 527. http://dx.doi.org/10.1007/ s11892-014-0527-8.

10. Kashyap, P. \& Farrugia, G. (2010). Diabetic gastroparesis: what we have learned and had to unlearn in the past 5 years. Gut., 59, 1716-1726.

11. Kindt, S., Dubois, D., Oudenhove, L.V., Caenepeel, P., Arts, J., Bisschops, R. \& Tack, J. (2009). Relationship between symptom pattern, assessed by the PAGI-SYM questionnaire, and gastric sensorimotor dysfunction in functional dyspepsia. Neurogastroenterol. Motil., 21, 1183-e105. doi: 10.1111/j.1365-2982.2009.01374.

12. Krishnan, B., Babu, S., Walker, J., Walker, A.B. \& Pappachan, J.M. (2013). Gastrointestinal complications of diabetes mellitus. World Journal of Diabetes, 4, 51-63. http://dx.doi.org/10.4239/wjd.v4.i3.51.

13. Majanovits, S. K., Zelits, M., Belantsits, A., Girotto, N., Licul, V. \& Shtimac, D. (2017). Diabetic gastroparesis - from diagnosis to gastric electrical stimulation treatment. Medicina fluminensis, 1, (53), 50-55. doi: 10.21860/medflum2017_173380.

14. Pop-Busui, R., Boulton, A.J.M., Feldman, E. L., Bril, V., Freeman, R., Malik, R.A., Sosenko, J.M. \& Ziegler, D. (2017). Diabetic neuropathy: a position statement by the American Diabetes Association. Diabetes Care, 40, 136154. doi: $10.2337 / \mathrm{dc} 16-2042$.

16. Revicki, D.A., Camilleri, M., Kuo, B., Norton, N.J., Murray, L., Palsgrove, A. \& Parkman, H.P. (2009). Development and content validity of a gastroparesis cardinal symptom index daily diary. Alimentary Pharmacology \& Therapeutics, 30, 670-680. doi:10.1111/j.1365-2036.2009.04078.

\title{
АКТУАЛЬНЫЕ ВОПРОСЫ РАННЕЙ ДИАГНОСТИКИ ДИАБЕТИЧЕСКОГО ГАСТРОПАРЕЗА В ПРАКТИКЕ СЕМЕЙНОГО ВРАЧА
}

○И. А. Костицкая

\author{
ГВУз «Ивано-Франковский национальный медицинский университет»
}

РЕЗЮМЕ. Целью исследования стало изучение вопроса ранней диагностики проявлений гастропареза у больных сахарным диабетом (СД) с помощью специфических анкет-опросников.

Материал и методы. Обследовано 240 больных СД, которым в качестве раннего скрининга дисмоторики желудка проведено анкетирование с использованием двух опросников: оценки симптомов, характерных для заболеваний верхнего отдела желудочно-кишечного тракта «Patient Assessment of Upper Gastrointestinal DisordersSymptoms" (PAGI-SYM) и определение индекса проявлений гастропареза "Gastroparesis Cardinal Symptom Index» (GCSI). Выполнена оценка надежности результатов анкетирования с определением коэффициента внутреннего соответствия и критериальной валидности по взаимосвязям шкал опросников с 13С-октаноевым дыхательным тестом (13С-ОДТ), которые определяли с помощью коэффициента корреляции. Статистическую обработку результатов проводили с помощью программы SPSS-15.

Результаты. У 36,6 \% больных СД 1 типа и у 43,3 \% больных СД 2 типа обнаружены симптомы диабетического гастропареза (ДГ). Установлена зависимость клинических проявлений осложнения с результатами 13С-ОДт. Предложен диагностический алгоритм: тщательное изучение жалоб обследованного и данных анамнеза жизни и заболевания, физикальный осмотр с последующим использованием опросников GCSI и оценкой результатов. Если сумма баллов составляла от 1 до 11 диагностировали легкую степень ДГ, 12-22 балла - средней тяжести, 23-33 балла - тяжелую, более 34 баллов - очень тяжелую. Для оценки М-ЭФ желудка выполнено 13С-ОДт: нормальный показатель - при времени полувыведения (Т 1/2) содержимого желудка в двенадцатиперстную кишку 40-75 минут, ускорение моторики, если Т 1/2 менее 40 минут, замедление моторики легкой степени - 75-95 минут, замедление средней степени - от 96 до 115 минут, замедление тяжелой степени - более 115 минут. Данный диагностический алгоритм позволяет семейным врачам своевременно диагностировать начальные признаки ДГ. 
Огляди літератури, оригінальні дослідження, погляд на проблему

Вывод. Рутинное использование специфических опросников способствует предупреждению неоправданной гипердиагностики, позволяет определить степень тяжести гастропареза у больных СД и обеспечить эффективность терапии.

КЛЮчЕВЫЕ СЛОВА: анкетирование; сахарный диабет; диабетический гастропарез; семейный врач.

\section{TOPICAL QUESTIONS OF THE EARLY DIAGNOSTICS OF DIABETIC GASTROPARESIS IN THE PRACTICE OF A FAMILY PHYSICIAN}

@I. O. Kostitska

\section{Ivano-Frankivsk National Medical University}

SUMMARY. The aim of the study was to investigate the issue of the early diagnostics of gastroparesis manifestations in patients with diabetes mellitus (DM) with the help of specific questionnaires.

Materials and Methods. 240 patients with DM were examined. They carried out a survey, as an early screening of motor dysfunction of the stomach, using two questionnaires: the evaluation of symptoms typical for diseases of the upper gastrointestinal tract «Patient Assessment of Upper Gastrointestinal Disorders-Symptoms» (PAGI-SYM) and the index definition of gastroparesis manifestations «Gastroparesis Cardinal Symptom Index» (GCSI). The assessment of the reliability of the survey results was completed with the determination of the coefficient of internal compliance and criteria validity through the correlations between questionnaires scales and the 13C-octane acid breath test (13C-OABT), which was determined with the help of the correlation coefficient. Statistical analysis of the results was performed using SPSS15.

Results. The symptoms of the diabetic gastroparesis (DG) were found in $36.7 \%$ of people with DM type 1 and in $43.3 \%$ of patients with DM type 2 . The relation between the clinical manifestations of complications and the results of 13C-OABT was established. It was suggested the diagnostic algorithm: a thorough study of the patient's complaints and anamnesis of life and disease, physical examination with the subsequent use of GCSI questionnaires and the evaluation of the results. If the total score is from 1 to 11 - light degree of DG, from 12 to 22 points - of the medium gravity, 23-33 - severe, and more than 34 points - very severe. To evaluate the M-EF of the stomach 13C-OABT was performed: normal index - the time of semi-ejection ( $\mathrm{T} 1 / 2)$ of gastric contents in the duodenum is 40-75 minutes, the acceleration of motility, if the $T 1 / 2$ is less than 40 minutes, the mild slowdown motility - 75-95 minutes, from 96 to 115 minutes - moderate slowdown, more than 115 minutes - severe slowdown. This diagnostic algorithm contributes to timely diagnosis of the early signs of DG by a family physician.

Conclusion. The routine use of specific questionnaires helps to prevent unjustified over diagnostics and allows determining the degree of severity of gastroparesis in patients with diabetes and the effectiveness of therapy.

KEY WORDS: questionnaire; diabetes mellitus; diabetic gastroparesis; family physician. 